\title{
Media surveillance, exit threats and earnings management of GEM companies
}

\author{
Qiqi Luo ${ }^{1, a,{ }^{*},}$ Xinxin $\mathrm{Yu}^{2, \mathrm{~b}}$ \\ 1,2,3Business Administration School, Hohai University, 213022 Changzhou, China \\ aemail, b1669828515@qq.com \\ ${ }^{*}$ Corresponding author
}

\begin{abstract}
Keywords: accrued earnings management, true earnings management, media oversight, exit
\end{abstract} threats, GEMP ublisher, Designing, Lowercase letters.

\begin{abstract}
This article selects GEM(Growth Enterprise Market) companies as the research object, intercepts the data since the establishment of the GEM board in 2009, and analyzes the relationship among corporate accrual earnings management, real earnings management, media supervision, and exit threats. It was found that media supervision would inhibit the accrued earnings management behavior of GEM companies, but the exit threat would increase the company's accrual earnings management behavior. As for the real earnings management , the media supervision has motivated the company to adopt more secret real earnings management behaviors, while the exit threat will inhibit its true earnings management behavior. In addition, in the act of accrual earnings management, media supervision and exit threats have an alternative relationship. But in real earnings management behavior, the two are complementary.
\end{abstract}

\section{Introduction}

Earnings management, as an enduring topic in the capital market, has always attracted much attention from the academic and practical circles. Some scholars believe that earnings management is the act of maximizing the operator's own interests or the market value of the enterprise through the choice of accounting policies within the scope allowed by generally accepted accounting standards. However, some scholars believe that earnings management is essentially a kind of "disclosure management" for obtaining private benefits. Nowadays, most companies regard earnings management as a decoration of financial fraud. How to prevent financial fraud and earnings management manipulation of listed companies has become the focus of scholars and practitioners.

In order to provide more convenient financing channels for SMEs to adjust the industrial structure, the China GEM (Growth Enterprise Market) Board was formally established on October 30, 2009. In terms of listing thresholds, review procedures, market supervision, etc., the requirements for GEM companies have been relaxed to increase the enthusiasm of the people for venture capital investment. However, due to the relaxation of regulatory requirements and the strong incentives of GEM companies to whitewash their operating results, GEM companies have become one of the main subjects of using earnings management to manipulate financial fraud.

In summary, the main contribution of this article is: in terms of research design, discussing accrual earnings management and true earnings management, this research path is considered more comprehensively. In terms of research content, the comprehensive effects of media supervision and exit threats on company earnings management are studied. In terms of research objects, most scholars select typical data of Shanghai and Shenzhen A-share listed companies, and lack of research on GEM listed companies. In addition, because exit threats are a new frontier research area[4] that has recently emerged in the accounting and finance community, there is little literature linking them to earnings management. For China's capital market, which is undergoing a transition period, it is particularly important to study the internal and external corporate governance mechanisms. 


\section{Empirical research}

\subsection{The role of media supervision in accounting earnings management}

Media supervision and accrual earnings management have a significant negative correlation at the level of $10 \%$, and the regression coefficient is -0.0045 , which indicates that media supervision can inhibit the company's accrual earnings management behavior to a certain extent. This is because the media attention has a supervisory effect on corporate earnings management behavior, and reports of corporate violations will attract the attention of various subjects, thus forcing managers to correct their own misconduct. Because accrual earnings management behavior is easier to find, and the media has information dissemination functions, it has a wide audience, including company shareholders, external creditors, consumers, and regulators. The company will reduce accrual earnings management manipulation because of the fear of the media's dissemination and supervision role. This is the same as the results of Qin Yihu ${ }^{[1]}$,Wu Chaopeng ${ }^{[2]}$ et al. ,Dai Yiyi ${ }^{[3]}$, and others.

\subsection{The role of exit threats in earnings management}

The exit threat is significantly positively correlated with accrual earnings management at $10 \%$, with a regression coefficient of 0.0040 . This shows that the exit threat will increase the company's accrual earnings management behavior to some extent. In the face of performance pressure, in order to maximize profits, institutional investors will relax supervision of corporate earnings management. Pound's[6] "strategic conspiracy hypothesis" believes that institutional investors may seek personal privacy through collusion with the management of listed companies. Chen et al. ${ }^{[4]}$ found that in the face of performance pressure, in order to maximize the benefits, institutional investors will relax supervision of corporate earnings management. Because under certain circumstances, corporate earnings management is also profitable for large external shareholders. Corporate earnings management can maximize the benefits of the three parties: controlling shareholders, management, and external major shareholders. From this perspective, the exit threat may induce the company's accrual earnings management behavior.

\subsection{The combined role of media supervision, exit threats, and corresponding earnings management}

Media * ET was significantly negatively correlated at the $10 \%$ level, with regression coefficients of -0.0012. This shows that there is a substitution effect between the media supervision and the exit threat. The exit threat will weaken the governance role of media supervision on earnings management. Media supervision can restrain the company's accrual earnings management behavior to a certain extent, but as the major shareholders threatened to withdraw may become "collusions" and stand in a stun with management, this will weaken the role of media supervision in corresponding earnings management.

Table1 Test results of accrual earnings management, media supervision, and exit threats

\begin{tabular}{cccc}
\hline AEM $\mid$ & $(1)$ & $(2)$ & $(3)$ \\
Media $\mid$ & $-0.0018357^{*}$ & & $-0.0045029^{*}$ \\
& $(-2.02)$ & $-1.86)$ \\
ET $\mid$ & & $0.0005518^{*}$ & $0.0040428^{*}$ \\
& & $(1.54)$ & $(1.74)$ \\
MediaET $\mid$ & & $-0.0012282^{*}$ \\
& & $(-1.72)$ \\
CFO $\mid$ & $-5.22 \mathrm{E}-12^{* * *}$ & $-5.1 \mathrm{E}-12^{* * *}$ & $-5.36 \mathrm{E}-12^{* * *}$ \\
& $(-4.25)$ & $(-4.15)$ & $(-4.34)$ \\
TAT2 $\mid$ & $0.0233924^{*}$ & $0.024163^{* *}$ & $0.0230546^{*}$ \\
& $(1.94)$ & $(2.01)$ & $(1.91)$ \\
EVM2 & $1.99 \mathrm{E}-06$ & 0.000000457 & $-2.14 \mathrm{E}-07$ \\
& $(0.05)$ & $(0.01)$ & $(0)$ \\
\hline
\end{tabular}




\subsection{The role of media supervision in real earnings management}

Media supervision and true earnings management are positively correlated at a significance level of $1 \%$, which indicates that the strengthening of media supervision will aggravate the degree of true earnings management of listed companies. This result can be explained by market pressure assumptions. The market pressure hypothesis believes that increasing media attention will promote managers' earnings management and make corporate earnings management manipulation more serious. The reasons mainly include the following two aspects: First, the increase in media attention will put market pressure on managers. Positive media coverage of the company's earnings information will boost investor confidence and raise the company's stock price. Out of the motivation of capital market performance, the company's major shareholders or managers will perform earnings management in order to meet or exceed public expectations. Second, individual investors dominate the market in Chinese stocks, and their level of specialization is low. Compared with other violations and manipulations of the company, earnings management is relatively hidden and harder to detect by media and individual investors (accounting for the majority of Chinese capital market investors) who lack professional knowledge. Therefore, companies tend to use earnings management methods to whitewash the company's operating conditions and conceal investors.

\subsection{The effect of exit threats on real earnings management}

The exit threat and earnings management behavior coefficient is negative and significant at the $10 \%$ level. This shows that the exit threat will to some extent inhibit the true earnings management behavior of enterprises. Shareholder governance plays an important role in the corporate governance framework. Because large external shareholders hold more shares, their stock market value is largely linked to corporate governance and performance, and has a strong incentive to participate in corporate governance. Large shareholders monitor the management to increase the value of the company (Shleifer and Vishny ${ }^{[5]}$ ), and they can obtain benefits from the value increase to cover the cost of supervision. The exit threat is a common method used by investors in the market. The exit threat of external major shareholders will change the perception of corporate decision makers, and then affect corporate governance by affecting management decisions. As an informed trader, external major shareholders will use the method of "voting with their feet" to punish managers' private behavior. The capital market often interprets the exit behavior of major external shareholders as negative news. Uninformed investors will adopt a strategy of shorting the company's stock, which will cause the company's stock price to fall sharply, threatening the value of the company and the private interests of insiders. Therefore, the exit threat can play a supervisory role and constrain management's true earnings management behavior to a certain extent.

\subsection{Media Surveillance and Exit Threat Together on Real Earnings Management}

The regression coefficients of the cross-terms of media surveillance and exit threats are positive, proving that the two have a mutual assistance effect on real earnings management. That is, the threat of shareholders' withdrawal will encourage the pressure of media oversight on the company, prompting the company to adopt more real earnings management behaviors. Due to the high shareholding of major shareholders and certain expertise, they are motivated and capable of paying attention to the operation of the company for personal interests. However, due to the collusion effect of the exit threat, the cases of collusion between major shareholders and management to hollow out listed companies have been repeatedly banned, and they cannot play their governance role in real earnings management. In view of this situation, the "public social devices" of the media seem even more important. As a relatively cheap way, media supervision will attract widespread social attention including company shareholders, which can restrict the accrued earnings manipulation of listed companies. When the exit threat does not adequately manage corporate earnings manipulation, media supervision will improve the situation to a certain extent. 
Table2 Test results of real earnings management, media supervision, and exit threats

\begin{tabular}{|c|c|c|c|}
\hline DREM & (1) & (2) & (3) \\
\hline \multirow[t]{2}{*}{ Media } & $0.0031 * *$ & & $0.0246635 * * *$ \\
\hline & (1.6) & & $(4.11)$ \\
\hline \multirow[t]{2}{*}{ ET } & & $0.0092287 * * *$ & $-0.0100408^{*}$ \\
\hline & & $(3.26)$ & $(-1.66)$ \\
\hline \multirow[t]{2}{*}{ MediaET | } & & & $0.0054755 * * *$ \\
\hline & & & $(4.10)$ \\
\hline \multirow[t]{2}{*}{$\mathrm{CFO}$} & $9.71 \mathrm{E}-12 * * *$ & $1.03 \mathrm{E}-11 * * *$ & $4.99 \mathrm{e}-12 * *$ \\
\hline & $(2.82)$ & $(3)$ & $(2.45)$ \\
\hline \multirow[t]{2}{*}{ TAT | } & -0.6304966 & $-0.6317219 * * *$ & $-0.1273759 * * *$ \\
\hline & $(-18.48)$ & $(-18.61)$ & $(-7.77)$ \\
\hline \multirow[t]{2}{*}{ EVM } & $-0.0003805 * * *$ & $-0.0003635 * * *$ & 0.0000933 \\
\hline & $(-3.17)$ & $(-3.04)$ & $(1.61)$ \\
\hline \multirow[t]{2}{*}{ AT $\mid$} & -0.0079177 & $-0.0078829 * * *$ & $-0.000076^{* *}$ \\
\hline & $(-2.9)$ & $(-2.89)$ & $(-2.62)$ \\
\hline \multirow[t]{2}{*}{$\mathrm{BS}$} & $0.0386752 * * *$ & $0.0372988 * * *$ & $0.0323435 *$ \\
\hline & $(2.12)$ & $(2.07)$ & $(1.67)$ \\
\hline \multirow[t]{2}{*}{ SGR | } & $-0.4296578 * * *$ & $-0.4340369 * * *$ & $-0.6842162 * * *$ \\
\hline & $(-4.41)$ & $(-4.5)$ & $(-9.47)$ \\
\hline
\end{tabular}

\section{Research conclusions and implications}

In modern society, media supervision and exit threats play an important role in monitoring the earnings management of listed companies, and have attracted the attention of academic and practical circles at home and abroad. This research takes GEM companies 'earnings management governance as the starting point, and studies the governance effects of media surveillance and exit threats on listed companies' earnings management. The research results show that:

(1) media supervision will inhibit the accrual earnings management behaviors of GEM companies, but it will prompt the companies to adopt more real earnings management behaviors that are more secretive and difficult to find.

(2) Withdrawal threat will increase the company's accrual earnings management behavior, but will inhibit its true earnings management behavior.

(3) In addition, in the act of accrual earnings management, media supervision and exit threats are a substitute relationship. But in real earnings management behavior, there is a complementary relationship between the two.

(4) Media supervision and exit threats have an important impact on the earnings management strategies of listed companies. That is, under pressure from media supervision, listed companies tend to use more real earnings management and less accrual earnings management. Large, listed companies' earnings management strategies will be more inclined to accrual earnings management.

\section{References:}

[1] Li Yan, Qin Yihu. Media supervision, reputation mechanism and resignation of independent directors [J]. Finance and Economics, 2011, (3): 36-41.

[2] Wu Chaopeng, Ye Xiaojie, Wu Shinong. Media supervision, political ties and executive change: Empirical evidence from China [J]. Economic Management, 2012, (2): 57-65.

[3] Dai Yiyi, Pan Yue, Chen Fen. Media supervision, government quality and auditor changes [J]. Accounting Research, 2013, (10): 89-95.

[4] Chen X, Lee C W J, Li J. Government assisted earnings management in China[J]. Journal of Accounting and Public Policy, 2008, 27( 3) : 262-274. 
[5] Shleifer A,Vishny R W. Large Shareholders and corporate control[J]. Journal of Political Economy, 1986, 94(3):461-488.

[6] Pound J. Proxy contests and the efficiency of shareholder oversight[J]. Journal of Financial Economics,1988,20: 237-265. 